PRACE GEOGRAFICZNE

zeszyt $163,2020,33-50$

doi: 10.4467/20833113PG.20.017.13213

Instytut Geografii i Gospodarki Przestrzennej UJ

Komisja Geograficzna, Polska Akademia Umiejętności

Wydawnictwo Uniwersytetu Jagiellońskiego

\title{
PRZESTRZEŃ PUBLICZNA KAMPUSU MORASKO W POZNANIU W OPINII STUDENTÓW ${ }^{1}$
}

\author{
Barbara Konecka-Szydtowska
}

\section{Public space of the Morasko Campus in Poznan in the opinion of students}

Abstract: Public spaces are an important part of urban space. The paper presents the results of the research on the assessment of the public space of the Morasko Campus situated in the northern part of Poznan. The analysis covers the years 2006 and 2017 and uses the semantic differential method worked out by Osgood, Succi and Tannenbaum in 1957. The study of public space was conducted in terms of five basic categories of spatial order: (1) town-planning - architectural order, (2) functional order, (3) aesthetic order, (4) social order and (5) ecological order. The obtained results show that, in the opinion of students, the Morasko space obtained a higher assessment in all the categories over the study period (an increase in the average assessment from 3.9 to 4.8). In 2017, ecological order was the category assessed highest, and functional order the one assessed lowest,. In the studied years the Campus space was assessed lowest by the students of the Faculty of Geographical and Geological Sciences, which was caused by its peripheral location. Due to the great importance of the natural values of the Campus, their detailed description is presented at the end of the study.

Keywords: public space, semantic differential, Morasko Campus, Poznań

\footnotetext{
${ }^{1}$ Niniejszy artykuł stanowi kontynuację i uzupełnienie treści zawartych w artykule: Kulczyńska i in. 2020 (w tym zeszycie).
} 
Zarys treści: Ważną częścią przestrzeni miejskiej są przestrzenie publiczne. W opracowaniu zaprezentowano wyniki badań na temat oceny przestrzeni Kampusu Morasko, położonego w północnej części Poznania. Zakres czasowy analizy obejmuje zasadniczo lata 2006 i 2017. W opracowaniu posłużono się metodą dyferencjału semantycznego opracowaną przez Osgooda, Succiego i Tannenbauma w 1957 r. Badanie przestrzeni publicznej przeprowadzono w odniesieniu do pięciu podstawowych kategorii ładu przestrzennego: 1) ładu urbanistyczno-architektonicznego, 2) ładu funkcjonalnego, 3) ładu estetycznego, 4) ładu społecznego oraz 5) ładu ekologicznego. Uzyskane wyniki pozwalają stwierdzić, że zdaniem studentów w badanym okresie nastąpił wzrost oceny przestrzeni Kampusu Morasko we wszystkich kategoriach (wzrost średniej oceny syntetycznej z 3,9 do 4,8). W 2017 r. zdecydowanie najwyżej ocenianą kategorią był ład ekologiczny, a najniżej ład funkcjonalny. W badanych latach najgorzej przestrzeń Kampusu oceniali studenci Wydziału Nauk Geograficznych i Geologicznych, co spowodowane było peryferyjną lokalizacją tego wydziału. Ze względu na duże znaczenie walorów przyrodniczych Kampusu w końcowej części pracy przeprowadzono ich pogłębioną charakterystykę.

Stowa kluczowe: przestrzeń publiczna, dyferencjał semantyczny, Kampus Morasko, Poznań

\section{Wprowadzenie}

Przestrzeń publiczna stanowi ważną część przestrzeni miejskiej (Liszewski 2001). Zdaniem Lorensa (2007) przestrzeń publiczna to „fragment przestrzeni miejskiej, który - poprzez sposób urządzenia oraz lokalizacji w strukturze urbanistycznej przeznaczony będzie na potrzeby realizacji bezpośrednich kontaktów pomiędzy uczestnikami życia społecznego oraz innych potrzeb społecznych korzystających z niej zbiorowości, pozostając jednocześnie fizycznie dostępnym dla wszystkich zainteresowanych osób”.

Nadrzędną cechą przestrzeni publicznej jest dostępność, czyli równoprawny dostęp wszystkich użytkowników. Jest to przestrzeń, do której dostęp ma każda jednostka bez konieczności spełniania dodatkowych, zewnętrznie narzuconych warunków. Jest to przestrzeń wspólna, w ramach której dochodzi do interakcji społecznych zgodnych z obowiązującym w danym społeczeństwie systemem wartości (Kowalczyk 2009). Ponadto miejskie przestrzenie publiczne cechuje otwartość, jawność i masowość, co stanowi przeciwwagę dla przestrzeni półpublicznych, półprywatnych, prywatnych i intymnych (Bartoszek i in. 1997; Hładkiewicz 2006; Cegłowska, Matykowski 2010; Bierwiaczonek, Nawrocki 2012). Dostępność, funkcjonalność, estetyka przestrzeni publicznych świadczą zarówno o jakości miasta, jak i jakości życia, współcześnie jednego z najistotniejszych czynników rozwoju.

Zakłada się, że właściwie kształtowana przestrzeń publiczna wpływa na jakość miasta i podnosi jakość życia jej użytkowników (w tym przypadku studentów), a także istotnie wpływa na kształtowanie i wzmacnianie więzi społecznych oraz 
tworzy tzw. megaprodukt miasta lub jego dzielnicy, którego społecznym wyrazem jest wizerunek i tożsamość (Markowski, 2007; Dębińska, Kołsut 2011). Najczęściej przestrzeń publiczna stanowi trzon miasta lub jego dzielnic, a użytkownicy korzystają z tej przestrzeni, w jakiś sposób postrzegają całą przestrzeń i jej elementy (percepcja), a następnie klasyfikują i porządkują, co prowadzi do oceny przestrzeni (waloryzacja) (Bartoszek i in. 1997). Do podstawowych przestrzeni publicznych w miastach należą: ulice, drogi, place oraz parki. Na przestrzeń publiczną składają się również różne dostępne budowle i budynki stanowiące własność publiczną (urzędy i instytucje publiczne, szkoły) oraz rozmaite formy krajobrazu przyrodniczego, będące własnością państwową lub gminną (Mierzejewska 2011).

Szczególnym przypadkiem miejskiej przestrzeni publicznej są kampusy uniwersyteckie. Należy podkreślić, że termin „kampus” w warunkach polskich w istotny sposób odbiega od tego, co rozumie się pod tym pojęciem w Stanach Zjednoczonych, Chinach czy Japonii. Słowo „kampus” określa tam wydzielone „miasteczko akademickie” z pełnym zapleczem naukowo-badawczym, dydaktycznym, socjalnym i mieszkalnym dla studentów i pracowników, gdzie zlokalizowane są również obiekty rekreacyjne, sportowe, gastronomiczne i rozrywkowe. W ciągu semestru większość studentów i profesorów nie opuszcza kampusu akademickiego, mając zapewnione wszystkie wygody niezbędne do mieszkania, pracy i wypoczynku. Natomiast w Polsce kampusem najczęściej bywa określany wydzielony teren miasta, uczelni (lub fragmentu uczelni), gdzie zgromadzona jest pewna liczba placówek naukowych, dydaktycznych, sportowych lub socjalnych dla studentów, stanowiących pewną enklawę, najczęściej jednak niezapewniającą kompleksowej obsługi naukowo-dydaktycznej, administracyjnej, rekreacyjnej czy mieszkalnej. Większość studentów i profesorów nie mieszka na terenie kampusu, a w ramach codziennych zajęć często przemieszcza się pomiędzy różnymi „kampusami” tej samej uczelni (Pilch 2017).

W zakresie lokalizacji obiektów szkolnictwa wyższego (jak i kampusów) w strukturze przestrzennej miasta wyróżnia się dwie podstawowe tendencje. Pierwsza związana jest z lokalizacją budynków uniwersyteckich w centrum miasta. Występuje w miastach europejskich posiadających tradycje kształcenia uniwersyteckiego sięgające średniowiecza (uniwersytety w Bolonii, Sorbona w Paryżu, Cambridge, Oxford). Dotyczy to również głównych ośrodków akademickich w Polsce. Są to nie tylko stare budynki uniwersyteckie, ale również nowe siedziby uczelni lokalizowane w centrum dla podkreślenia więzi z miastem. Drugim typowym miejscem lokalizacji uniwersytetu w strukturze przestrzennej miasta jest budowa miasteczka uniwersyteckiego (kampusu uniwersyteckiego) na peryferiach miasta. Najwcześniej tego typu kampusy pojawiły się w Stanach Zjednoczonych, gdzie stanowią wyodrębnione, odpowiednio zaplanowane strefy poza obszarem miasta (Słodczyk 2003). Idea budowy miasteczek uniwersyteckich przeniknęła do Polski po II wojnie 
Światowej. Pierwsze tego typu ośrodki powstały w Toruniu, Olsztynie i Lublinie. Ostatnie dwie największe inwestycje to budowa Kampusu 600-lecia Odnowienia Uniwersytetu Jagiellońskiego w Krakowie i budowa Kampusu Uniwersyteckiego Morasko w Poznaniu, którą rozpoczęto w latach 80. XX w.

Kampus Morasko zajmujący powierzchnię ok. 300 ha, zlokalizowany jest w peryferyjnej, północnej części miasta. W strukturze przestrzennej Kampusu można wydzielić dwa miejsca lokalizacji budynków naukowo-dydaktycznych, są to tereny zachodnie, gdzie znajduje się większość budynków i północno-wschodnie tylko z jednym wydziałem. Uzupełnieniem dominującej funkcji akademickiej Kampusu są funkcje rekreacyjno-sportowe, usługowe i mieszkaniowe ${ }^{2}$. Istotną cechą odróżniającą przestrzeń Kampusu Morasko od przestrzeni akademickich zlokalizowanych w centrum miasta są jej bogate walory przyrodnicze wykorzystane w zaprojektowaniu koncepcji parku naturalistycznego w powiązaniu z otaczającymi kompleksami leśnymi i zbiornikami wodnymi.

Celem opracowania jest ocena przestrzeni publicznej Kampusu Uniwersyteckiego w Poznaniu przez studentów. Badanie przestrzeni Kampusu przeprowadzono w odniesieniu do pięciu podstawowych kategorii ładu przestrzennego, przy wykorzystaniu metody dyferencjału semantycznego. Zakres czasowy analizy obejmuje zasadniczo lata 2006 i 2017. W celu realizacji głównego celu pracy formułuje się następujące pytania poznawcze: 1) Czy w badanych latach zmienia się zasadniczo ocena przestrzeni publicznej Kampusu?, 2) Czy studenci różnych wydziałów podobnie postrzegają i oceniają przestrzeń Kampusu?, 3) Czy istnieje zróżnicowanie w ocenie przestrzeni w odniesieniu do różnych jej kategorii?

\section{Postępowanie badawcze}

W badaniach związanych z oceną przestrzeni publicznej Kampusu Morasko zastosowano metodę dyferencjału semantycznego. Metoda opracowana przez C.E. Osgooda, G.J. Succiego, P.H. Tannenbauma w 1957 r. służy ilościowej ocenie obrazu (wyobrażeń) obiektu, jaki posiada badana osoba. Uniwersalność metody powoduje, że jest ona powszechnie stosowana na gruncie nauk socjologicznych, psychologicznych czy geograficznych (Burgess 1978; Mayntz i in. 1985; Babbie 2005). Jedną z zalet metody jest możliwość oceny bardzo różnych obiektów, do których należą m. in.: a) dany obszar, np. przestrzeń małego miasta czy dzielnicy miasta, gdy bada się jej obraz, jaki istnieje w świadomości mieszkańców. Badania na ten temat prowadzili m.in.: H. Libura (1988), K. Wódz (1991), J. Kotus (1999), Madurowicz (2007), B. Konecka-Szydłowska (2016), b) konkretna osoba, np. burmistrz, nauczyciel, lekarz,

\footnotetext{
${ }^{2}$ Więcej na temat funkcji akademickiej, rekreacyjno-sportowej, usługowej i mieszkaniowej znajduje się w artykule: Kulczyńska i in. 2020 (w tym zeszycie).
} 
którą bada się ze względu na jej odbiór społeczny (obraz w świadomości mieszkańców), czy c) inne pojęcia, np. nazwy własne, gdy bada się zgodność proponowanej nazwy z wizerunkiem przedmiotu, którego ta nazwa dotyczy.

Badanie percepcji i następnie oceny przestrzeni publicznej Kampusu Morasko w Poznaniu przeprowadzono w odniesieniu do pięciu wybranych kategorii ładu przestrzennego: 1) ładu urbanistyczno-architektonicznego, którego najistotniejszą cechą jest zwartość kompozycji przestrzennej, 2) ładu funkcjonalnego związanego z wygodą życia w aspekcie wyposażenia w elementy infrastruktury technicznej i społecznej, 3) ładu estetycznego określającego urodę miejsca i przestrzeni, 4) ładu społecznego odnoszącego się do jednostkowej i zbiorowej identyfikacji z miejscem i przestrzenią oraz 5) ładu ekologicznego związanego z wartością środowiska naturalnego (Wódz 1991; Bartoszek i in. 1997). Podstawą analizy było wydzielenie 12 par przeciwstawnych (opozycyjnych) własności (cech) określających przestrzeń publiczną Kampusu. Tylko te pary własności przedstawiono respondentom (studentom) do oceny (w ankiecie nie posługiwano się pojęciem ładu przestrzennego). Podczas opracowywania wyników każda para przeciwstawnych własności traktowana jest jako kontinuum składające się z sześciu członów: od 6 - mocne wskazanie pozytywne do 1 - mocne wskazanie negatywne (liczba członów na kontinuum może być różna i wynosi najczęściej od 5 do 7). Kategorię ład urbanistyczno-architektoniczny opisują dwie pary własności (pary cech): przestrzeń zwarta - rozproszona, uporządkowana - chaotyczna; kategoria ładu funkcjonalnego określona jest przez dwie pary: nasycenie infrastrukturą społeczną brak nasycenia infrastrukturą społeczną, dobre funkcjonowanie infrastruktury technicznej - złe funkcjonowanie infrastruktury technicznej; ład estetyczny określają cztery własności: przestrzeń ładna - brzydka, czysta - brudna, kolorowa - szara, bogata szata informacyjna - uboga szata informacyjna; kategorię ładu społecznego opisują dwie pary: poczucie bycia u siebie - poczucie zagubienia, przestrzeń bezpieczna - niebezpieczna; ostatnią kategorię ładu ekologicznego tworzą dwie pary: zielone otoczenie - kamienna pustynia, środowisko czyste - środowisko zanieczyszczone (tab. 1). Należy podkreślić, że w przypadku par własności opisujących ład funkcjonalny wprowadzono komentarz objaśniający. W odniesieniu do infrastruktury społecznej wymieniono jej składowe, do których należą: handel, ochrona zdrowia, edukacja, pozostałe usługi. Natomiast w przypadku infrastruktury technicznej najbardziej istotna była ogólna dostępność komunikacyjna Kampusu i jej elementy (sieć drogowa, przystanki autobusowe, parkingi, stacje rowerowe). Zadaniem respondenta było postawienie krzyżyka przy jednej z wartości od 6 do 1 , co wyrażało jego emocjonalne nastawienie do każdej pary przeciwstawnych własności przestrzeni. Następnie na podstawie uzyskanych wskazań dla każdej pary obliczano wartość średniej arytmetycznej ważonej, która jest tożsama z końcową oceną (Konecka-Szydłowska, Kulczyńska 2012). 
Tab. 1. Skalowanie własności przestrzeni publicznej Kampusu Morasko

Table 1. Scaling of the properties of public space of the Morasko Campus

\begin{tabular}{|c|c|c|c|c|c|c|c|c|}
\hline $\begin{array}{c}\text { Kategoria ładu } \\
\text { przestrzennego } \\
\text { Spatial order category }\end{array}$ & $\begin{array}{l}\text { Własność pozytywna } \\
\text { Positive property }\end{array}$ & 6 & 5 & 4 & 3 & 2 & 1 & $\begin{array}{l}\text { Własność negatywna } \\
\text { Negative property }\end{array}$ \\
\hline \multirow{2}{*}{$\begin{array}{l}\text { ład urbanistyczno- } \\
\text { architektoniczny } \\
\text { urban and architectural } \\
\text { order }\end{array}$} & $\begin{array}{l}\text { zwarta } \\
\text { compact }\end{array}$ & & & & & & & $\begin{array}{l}\text { rozproszona } \\
\text { dispersed }\end{array}$ \\
\hline & $\begin{array}{l}\text { uporządkowana } \\
\text { orderly }\end{array}$ & & & & & & & $\begin{array}{l}\text { chaotyczna } \\
\text { chaotic }\end{array}$ \\
\hline \multirow{2}{*}{$\begin{array}{l}\text { ład funkcjonalny } \\
\text { functional order }\end{array}$} & $\begin{array}{l}\text { nasycenie infrastrukturą } \\
\text { społeczną } \\
\text { abundance of social } \\
\text { infrastructure }\end{array}$ & & & & & & & $\begin{array}{l}\text { brak nasycenia infrastrukturą } \\
\text { społeczną } \\
\text { lack of social infrastructure }\end{array}$ \\
\hline & $\begin{array}{l}\text { dobre funkcjonowanie } \\
\text { infrastruktury technicznej } \\
\text { good functioning of } \\
\text { technical infrastructure }\end{array}$ & & & & & & & $\begin{array}{l}\text { złe funkcjonowanie infrastruktury } \\
\text { technicznej } \\
\text { bad functioning of technical } \\
\text { infrastructure }\end{array}$ \\
\hline \multirow{4}{*}{$\begin{array}{l}\text { ład estetyczny } \\
\text { aesthetic order }\end{array}$} & $\begin{array}{l}\text { ładna } \\
\text { beautiful }\end{array}$ & & & & & & & $\begin{array}{l}\text { brzydka } \\
\text { ugly }\end{array}$ \\
\hline & $\begin{array}{l}\text { Czysta } \\
\text { clean }\end{array}$ & & & & & & & $\begin{array}{l}\text { brudna } \\
\text { dirty }\end{array}$ \\
\hline & $\begin{array}{l}\text { pełna kolorów } \\
\text { colourful }\end{array}$ & & & & & & & $\begin{array}{l}\text { szara } \\
\text { grey }\end{array}$ \\
\hline & $\begin{array}{l}\text { bogata szata } \\
\text { informacyjna } \\
\text { rich in information }\end{array}$ & & & & & & & $\begin{array}{l}\text { uboga szata informacyjna } \\
\text { poor in information }\end{array}$ \\
\hline \multirow{2}{*}{$\begin{array}{l}\text { ład społeczny } \\
\text { social order }\end{array}$} & $\begin{array}{l}\text { poczucie bycia u siebie } \\
\text { feeling at home }\end{array}$ & & & & & & & $\begin{array}{l}\text { poczucie zagubienia } \\
\text { feeling lost }\end{array}$ \\
\hline & $\begin{array}{l}\text { bezpieczna } \\
\text { safe }\end{array}$ & & & & & & & $\begin{array}{l}\text { niebezpieczna } \\
\text { dangerous }\end{array}$ \\
\hline \multirow{2}{*}{$\begin{array}{l}\text { ład ekologiczny } \\
\text { ecological order }\end{array}$} & $\begin{array}{l}\text { zielone otoczenie } \\
\text { green surroundings }\end{array}$ & & & & & & & $\begin{array}{l}\text { kamienna pustynia } \\
\text { stone desert }\end{array}$ \\
\hline & $\begin{array}{l}\text { środowisko czyste } \\
\text { clean environment }\end{array}$ & & & & & & & $\begin{array}{l}\text { środowisko zanieczyszczone } \\
\text { polluted environment }\end{array}$ \\
\hline
\end{tabular}

Badanie percepcji przestrzeni Kampusu Morasko w opinii studentów przeprowadzono przy wykorzystaniu narzędzia badawczego, jakim była ankieta oparta o metodę dyferencjału semantycznego. Badania ankietowe przeprowadzono głównie w formie tradycyjnej, z niewielkim udziałem formy zdalnej. Badania wykonano zasadniczo w dwóch turach: w 2006 r. i 2017 r., oraz ze względu na specyfikę uzyskanych odpowiedzi - dodatkowo w 2019 r. wśród studentów Wydziału Nauk Geograficznych i Geologicznych. Podstawowymi elementami ankiety były tabela zawierająca badane własności przestrzeni Kampusu oraz metryczka respondenta. Ponadto w 2017 r. 
i w 2019 r. ankieta dawała możliwość wpisania fakultatywnych uwag respondenta, w tym na temat brakujących obiektów. W 2006 r. w badaniach uczestniczyła grupa respondentów licząca 200 osób, zróżnicowana pod względem płci, etapu nauki oraz poszczególnych wydziałów. Badaniami objęto studentów wydziałów zlokalizowanych w zachodniej części Kampusu: Wydziału Fizyki, Wydziału Biologii i Wydziału Matematyki i Informatyki, oraz Wydziału Nauk Geograficznych i Geologicznych znajdującego się we wschodniej części badanego obszaru³. Natomiast w 2017 r. w ankiecie wzięło udział 240 respondentów z wyżej wymienionych wydziałów oraz dodatkowo z funkcjonujących już wówczas w zachodniej części Kampusu: Wydziału Chemii, Wydziału Historycznego oraz Wydziału Nauk Politycznych i Dziennikarstwa ${ }^{4}$. Grupa studentów przebadana w 2019 r. liczyła 35 osób. Powtórne badanie zostało przeprowadzone w celu przeanalizowania zmian postrzegania obszaru Kampusu wśród studentów. We wszystkich przypadkach wykorzystano tę samą metodę badań, a mianowicie skalę dyferencjału semantycznego. Badanie percepcji zostało przeprowadzone na podstawie pięciu kategorii ładu przestrzennego w odniesieniu do 12 własności przestrzeni.

\section{Ocena przestrzeni Kampusu Morasko}

Celem opracowania jest analiza postrzegania (percepcji) i wartościowania (waloryzacji) przestrzeni publicznej Kampusu Morasko w Poznaniu przez studentów. Wyniki badań przedstawiono w odniesieniu do następujących konfiguracji: 1) ocena przestrzeni Kampusu przez studentów wszystkich wydziałów w układzie 12 par przeciwstawnych własności, 2) ocena przestrzeni Kampusu przez studentów różnych wydziałów w układzie pięciu kategorii ładu przestrzennego, 3) ocena przestrzeni Kampusu przez studentów Wydziału Nauk Geograficznych i Geologicznych w układzie 12 par przeciwstawnych własności.

Uzyskane oceny przestrzeni Kampusu w układzie 12 par przeciwstawnych własności dla grupy studentów wszystkich wydziałów pozwalają stwierdzić, że w obu badanych latach rozpiętość między najwyższą i najniższą oceną była zbliżona. W 2006 r. kształtowała się na poziomie 2,5 i wahała się od wartości 2,5 (infrastruktura techniczna)

\footnotetext{
${ }^{3}$ Szczegółowa mapa Kampusu Morasko (ryc. 1) i etapy rozwoju (tab. 1) znajdują się w artykule: Kulczyńska i in. 2020 (w tym zeszycie).

${ }^{4}$ W wyniku rozwoju Kampusu i przekształceń strukturalnych w ramach wydziałów z dniem 1 października 2019 r. w zachodniej części Kampusu Morasko funkcjonują: Wydział Fizyki, Wydział Matematyki i Informatyki, Wydział Biologii, Wydział Nauk Politycznych i Dziennikarstwa, Wydział Chemii, Wydział Historii, Wydział Archeologii, natomiast w zachodniej części: Wydział Geografii Społeczno-Ekonomicznej i Gospodarki Przestrzennej (WGSEiGP) oraz Wydział Nauk Geograficznych i Geologicznych (WNGIG).
} 
do 5,0 (czyste środowisko), natomiast w 2017 r. wynosiła 2,4, lecz rozciągała się od poziomu 3,5 (infrastruktura społeczna) do 5,9 (zielone otoczenie). W 2006 r. trzema najwyżej ocenianymi cechami Kampusu były: czyste środowisko $(5,0)$, zielone otoczenie $(4,9)$ i ładna przestrzeń $(4,7)$. W 2017 r. przy istotnym wzroście ocen były to własności: zielone otoczenie $(5,9)$ i czyste środowisko $(5,8)$, a także poczucie bycia u siebie (5,7). W 2006 r. studenci najniżej ocenili: infrastrukturę techniczną $(2,5)$ i społeczną $(2,7)$ Kampusu oraz jego szatę informacyjną $(2,9)$. W kolejnym roku również relatywnie nisko została oceniona infrastruktura społeczna $(3,5)$ i szata informacyjna $(3,9)$ (ryc. 1). W badanym okresie nie odnotowano spadku w ocenie wartości żadnej z cech przestrzeni Kampusu, czego następstwem był ogólny wzrost oceny syntetycznej z wartości 3,9 w 2006 r. do 4,8 w 2017 r. W układzie wyróżnionych par własności najbardziej widoczna poprawa w percepcji przestrzeni Kampusu dotyczyła cech związanych z funkcjonowaniem infrastruktury technicznej (z 2,5 do 4,3), uporządkowaniem przestrzeni (z 3,8 do 5,3) i poczuciem bycia u siebie (z 4,3 do 5,7). Należy sądzić, że wzrost ocen przestrzeni Kampusu Morasko we wszystkich aspektach ma związek z zachodzącymi zmianami w układzie poszczególnych kategorii ładu przestrzennego. Przykładowo zmiany w zakresie ładu urbanistyczno-architektonicznego należy wiązać z budową nowych wydziałów, obiektów naukowych i sportowych (głównie w części zachodniej Kampusu), a zmiany w zakresie ładu funkcjonalnego z poprawą dostępności komunikacyjnej (lokalizacja przystanków autobusowych i stacji rowerowych) czy wzrostem nasycenia podmiotami usługowymi, w tym handlowymi i gastronomicznymi ${ }^{5}$. Natomiast do podwyższenia oceny w kategorii ładu ekologicznego przyczynił się wzrost elementów zagospodarowania przyrodniczego (o czym szerzej w dalszej części artykułu).

Wyniki badań ankietowych w zakresie oceny przestrzeni Kampusu przez studentów różnych wydziałów w odniesieniu do pięciu kategorii ładu przestrzennego, przedstawiono w układzie trzech warstw: 1) oceny studentów wszystkich wydziałów, 2) oceny studentów Wydziału Nauk Geograficznych i Geologicznych, zlokalizowanego w części wschodniej Kampusu, 3) oceny studentów wydziałów zlokalizowanych w części zachodniej Kampusu (tab. 2). Ocena syntetyczna przestrzeni Kampusu uzależniona była od przynależności ankietowanych studentów do określonego wydziału i od kategorii ładu przestrzennego. Zdecydowanie lepiej przestrzeń Kampusu ocenili studenci wydziałów zlokalizowanych w jego zachodniej części. Ich oceny były bardzo zbliżone, dlatego dokonano ich zgrupowania i obliczenia oceny średniej, która wynosiła 4,2 w 2006 r. i 5,1 w 2017 r. Zdecydowanie mniej pozytywny obraz Kampusu mieli studenci Wydziału Nauk Geograficznych i Geologicznych, na co wskazują oceny średnie, które kształtowały się na wyraźnie niższym poziomie i wynosiły

${ }^{5}$ Szerzej na temat zmian zachodzących w strukturze przestrzenno-funkcjonalnej Kampusu w artykule: Kulczyńska i in. 2020 (w tym zeszycie). 


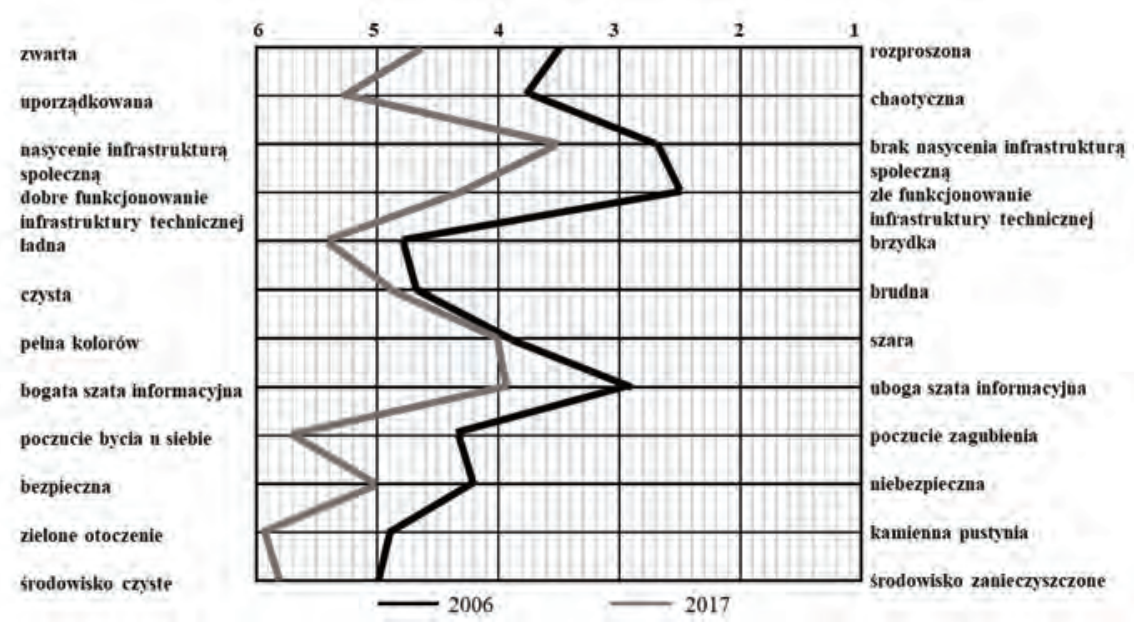

Ryc.1. Ocena przestrzeni Kampusu przez studentów wszystkich wydziałów w 2006 r. i 2017 r. Fig. 1. Assessment of the Morasko Campus space by students of all the faculties in 2006 and 2017

odpowiednio 3,6 i 4,5. Wydział ten znajduje się w części wschodniej Kampusu i jest odizolowany od pozostałych wydziałów przestrzenią o funkcjach mieszkaniowych i rekreacyjno-sportowych. Dodatkowo cechuje go gorsza dostępność komunikacyjna w porównaniu z budynkami uniwersyteckimi zlokalizowanymi w zachodniej części Kampusu, które położone są w bliskiej odległości od końcowego przystanku Poznańskiego Szybkiego Tramwaju (PST, tzw. „Pestka”) (Beim, Modrzewski 2008).

Na podstawie opinii wszystkich studentów można stwierdzić, że w odniesieniu do pięciu analizowanych kategorii ładu przestrzennego w obu porównywanych okresach najwyżej ocenianą kategorią był ład ekologiczny, związany z takimi cechami jak zielone otoczenie i czyste środowisko. Oceny średnie tej kategorii dla wszystkich wydziałów wynosiły 4,9 w 2006 r. i 5,7 w 2017 r., a ich rozpiętość wahała się od wartości 4,8 (2006 r., WNGiG) do 5,9 (2017 r., pozostałe wydziały). Ze względu na peryferyjne położenie Kampusu w północnej części Poznania oraz występujące tutaj walory przyrodnicze i ich zagospodarowanie, sytuacja taka była do przewidzenia. $Z$ kolei zdecydowanie najniższe oceny otrzymał ład funkcjonalny związany z poziomem wyposażenia oraz rozwojem infrastruktury społecznej i technicznej Kampusu. Oceny średnie dla wszystkich wydziałów kształtowały się na poziomie 2,6 w 2006 r. oraz 3,9 w 2017 r., a wahały się od 2,2 (2006 r. WNGiG) do 4, 1 (2017 r., pozostałe wydziały). Tak niskie oceny są również po części następstwem peryferyjnego położenia 
Tab. 2. Ocena syntetyczna przestrzeni Kampusu Morasko w 2006 r. i 2017 r.

Table 2. Synthetic assessment of the Morasko Campus space in 2006 and 2017

\begin{tabular}{|c|c|c|c|c|c|c|}
\hline \multirow{3}{*}{$\begin{array}{c}\text { Kategoria tadu } \\
\text { przestrzennego } \\
\text { Spatial order category }\end{array}$} & \multicolumn{6}{|c|}{$\begin{array}{l}\text { Ocena syntetyczna przestrzeni } \\
\text { Synthetic assessment of space }\end{array}$} \\
\hline & \multicolumn{2}{|c|}{$\begin{array}{l}\text { Studenci wszystkich } \\
\text { wydziałów } \\
\text { Students of all } \\
\text { faculties }\end{array}$} & \multicolumn{2}{|c|}{$\begin{array}{l}\text { Studenci Wydziału Nauk } \\
\text { Geograficznych i Geologicznych } \\
\text { (wschodnia część) } \\
\text { Students of the Faculty } \\
\text { of Geographical and Geological } \\
\text { Sciences (eastern part) }\end{array}$} & \multicolumn{2}{|c|}{$\begin{array}{l}\text { Studenci pozostałych } \\
\text { wydziałów } \\
\text { (zachodnia czéść) } \\
\text { Students of other faculties } \\
\text { (western part) }\end{array}$} \\
\hline & 2006 & 2017 & 2006 & 2017 & 2006 & 2017 \\
\hline $\begin{array}{l}\text { ład urbanistyczno- } \\
\text { architektoniczny } \\
\text { urban and architectural } \\
\text { order }\end{array}$ & 3,7 & 5,0 & 3,1 & 4,6 & 4,3 & 5,3 \\
\hline $\begin{array}{l}\text { ład funkcjonalny } \\
\text { functional order }\end{array}$ & 2,6 & 3,9 & 2,2 & 3,5 & 2,9 & 4,1 \\
\hline $\begin{array}{l}\text { ład estetyczny } \\
\text { aesthetic order }\end{array}$ & 4,1 & 4,5 & 4,0 & 4,1 & 4,2 & 4,9 \\
\hline $\begin{array}{l}\text { ład społeczny } \\
\text { social order }\end{array}$ & 4,2 & 5,3 & 3,8 & 5,0 & 4,5 & 5,4 \\
\hline $\begin{array}{l}\text { ład ekologiczny } \\
\text { ecological order }\end{array}$ & 4,9 & 5,7 & 4,8 & 5,6 & 5,1 & 5,9 \\
\hline $\begin{array}{l}\text { ocena średnia } \\
\text { average value }\end{array}$ & 3,9 & 4,8 & 3.6 & 4,5 & 4,2 & 5,1 \\
\hline
\end{tabular}

Kampusu i wynikającej z tego faktu jego trudniejszej, w stosunku do budynków akademickich zlokalizowanych w centrum miasta, dostępności komunikacyjnej oraz następstwem niedoinwestowania w placówki infrastruktury społecznej. Studenci Wydziału Nauk Geograficznych i Geologicznych mieli odmienne zdanie od pozostałych respondentów w odniesieniu do pozostałych kategorii ładu przestrzennego, które ocenili gorzej w obu okresach. Ich zdaniem przestrzeń Kampusu w aspekcie ładu urbanistyczno-architektonicznego jest mniej zwarta i bardziej chaotyczna, w zakresie ładu estetycznego mniej ładna i czysta, a także o dość ubogiej szacie informacyjnej, zaś w odniesieniu do ładu społecznego niedająca poczucia bycia u siebie.

W trakcie badań ankietowych w 2017 r. zadano dodatkowo wszystkim studentom pytanie: jakich obiektów ich zdaniem brakuje na Kampusie. Najwięcej braków dotyczyło szeroko pojmowanej infrastruktury społecznej, gdyż według 91\% ankietowanych na obszarze Kampusu występuje niedobór placówek handlowo-gastronomicznych takich jak: sklepy spożywcze, piekarnie czy bary szybkiej obsługi i pizzerie, w opinii jednego z respondentów: „brakuje infrastruktury usługowej, np. sklepów 
spożywczych, obiektów gastronomicznych”. Zdaniem 5\% badanych na obszarze tym brakuje domów akademickich. Nieliczna grupa respondentów (tylko 3\%) uznała, że na obszarze Kampusu brakuje również większej liczby ławek zewnętrznych.

Ze względu na specyfikę uzyskanych odpowiedzi i wyraźnie gorszy odbiór przestrzeni publicznej Kampusu przez studentów Wydziału Nauk Geograficznych i Geologicznych, powtórzono badanie percepcji przestrzeni w tej grupie studentów w 2019 r. W pewnym sensie otrzymane wyniki są zaskakujące, gdyż wskazują na niższą ocenę przestrzeni w stosunku do 2017 r. (spadek średniej syntetycznej z 4,5 do 4,1). W układzie 12 par przeciwstawnych własności, które odpowiadają pięciu kategoriom ładu przestrzennego, najbardziej wyraźny spadek odnotowano w kategorii oceny ładu urbanistyczno-architektonicznego (spadek z 4,6 do 3,6) w zakresie takich cech jak: przestrzeń zwarta i uporządkowana oraz ładu społecznego (spadek z 5, 0 do 4,0) w odniesieniu do cech przestrzeń bezpieczna i poczucie bycia u siebie (ryc. 2). Pozostałe kategorie ładu oceniono na podobnym poziomie. Konkluzję tej części pracy mogą stanowić opinie studentów Wydziału Nauk Geograficznych i Geologicznych:,,przestrzeń jest niejednolita, przytłaczająca i chaotyczna”, a „barierą nie są odległości od przystanków, ale peryferyjne położenie względem innych części Kampusu”.



Ryc. 2. Ocena przestrzeni Kampusu przez studentów Wydziału Nauk Geograficznych i Geologicznych w 2006 r., 2017 r. i 2019 r.

Fig. 2. Assessment of the Morasko Campus space by students of the Faculty of Geographical and Geological Sciences in 2006, 2017 and 2019 


\section{Walory przyrodnicze Kampusu Morasko}

Zdecydowanie najważniejszą cechą przestrzeni publicznej wyróżniającą Kampus Morasko od innych obszarów akademickich zlokalizowanych w centrum miasta są jej walory przyrodnicze związane z funkcją rekreacyjną i możliwością aktywnego wypoczynku. Występowanie na terenie Kampusu dużych powierzchni dobrze zagospodarowanych terenów zieleni w połączeniu z otaczającymi kompleksami leśnymi i elementami wodnymi (strumień Różany Potok, zbiorniki wodne) w zasadniczym stopniu wpłynęło na najwyższe oceny przestrzeni Kampusu w kategorii ładu ekologicznego w całym badanym okresie. W związku z tym poniżej przedstawiono ich szerszą charakterystykę.

Za początek prac związanych z przyrodniczym zagospodarowaniem terenów powstającego Kampusu należy uznać rok 1977, kiedy nastąpiło przekazanie przez Ogród Botaniczny UAM w Poznaniu głazu narzutowego jako kamienia węgielnego i wmurowanie aktu erekcyjnego. Akt erekcyjny podpisali przedstawiciele władz centralnych: Minister Nauki, Szkolnictwa Wyższego i Techniki, Kierownik Wydziału Nauki i Oświaty Komitetu Centralnego Polskiej Zjednoczonej Partii Robotniczej oraz przedstawiciele ówczesnych władz miasta Poznania. Okazały głaz narzutowy został ustawiony na najwyższym wzniesieniu Kampusu Morasko. Zasadnicze rozpoczęcie prac nastąpiło po 1990 r. i związane było z zagospodarowaniem terenu o powierzchni 3 ha, położonego między ulicą Umultowską od wschodu a zabudowaniami powstającego Wydziału Fizyki od zachodu. Jako dominującą przyjęto koncepcję parku naturalistycznego opracowaną przez prof. dr. hab. A. Łukasiewicza i realizowaną pod kierunkiem dr. S. Łukasiewicza z Ogrodu Botanicznego UAM. Sformułowanie „park naturalistyczny” oznacza „wtopienie” terenu w otaczający krajobraz, tj. zharmonizowanie projektowanych powierzchni z charakterem otoczenia, powiązanie z istniejącymi kompleksami leśnymi oraz dostosowanie wprowadzonych gatunków roślin do warunków środowiska glebowego. Pierwszym zadaniem w ramach zagospodarowania terenu przyszłego parku było usunięcie zanieczyszczeń, gdyż teren był silnie zdegradowany i zaśmiecony. W kolejnym etapie, w 1995 r., odtworzono całkowicie zarośnięte jeziorko w kształcie wydłużonej „kropli”. Zbiornik ten wraz z sąsiadującym z nim od północy drugim akwenem tworzy system retencjonowania wód na tym obszarze. Jednocześnie przez kilka lat prowadzono biologiczną rekultywację terenu poprzez wprowadzanie przedplonów i użyźnianie nawozami mineralnymi. Dopiero po zakończeniu rekultywacji gleb przystąpiono do celowego, przyrodniczego zagospodarowania terenu. Wprowadzono takie założenia kompozycyjne jak osie i perspektywy widokowe, które zapewniają rozległe widoki ze wzniesienia z kamieniem węgielnym i od strony wejść na jego powierzchnię ze wszystkich kierunków, a umiejętnie przeprowadzona sieć dróg funkcjonalnie scala obszar parku. Ostatnim etapem zagospodarowania parku było posadzenie roślin, 
głównie drzew i krzewów (ok. 200 gatunków), i rozmieszczenie głazów narzutowych pełniących funkcje dekoracyjne.

Uniwersytecki park, od 2020 r. noszący nazwę skweru Poznańskiego Towarzystwa Przyjaciół Nauk, jest przykładem nowoczesnego rozwiązania i właściwego zagospodarowania przyrodniczego przestrzeni Kampusu. Dobrze łączy się z otaczającą, naturalną przyrodą oraz z zielenią wokół wszystkich obiektów uniwersyteckich, zaprojektowaną przez pracowników Ogrodu Botanicznego UAM w Poznaniu (Łukasiewicz 1998; Łukasiewicz 2005). Ogród Botaniczny UAM świadczy usługi na rzecz licznych obiektów uniwersyteckich i jest aktywnie zaangażowany w urządzanie terenów zieleni na Kampusie Morasko. Dnia 9 czerwca 2003 r. zarządzeniem J.M. Rektora prof. dr. hab. Stanisława Lorenca została powołana sekcja ds. utrzymania terenów zieleni UAM. W ramach jej działalności przygotowano oraz zrealizowano projekty urządzenia zieleni na licznych obiektach uniwersyteckich, m.in. wokół budynków Wydziału Biologii oraz Wydziału Nauk Geograficznych i Geologicznych.

Należy podkreślić, że najbliższe otoczenie oraz dziedzińce każdego z wydziałów posiadają zagospodarowane tereny zieleni z elementami małej architektury ogrodowej (klomby, kwietniki) wykorzystywane przez studentów i pracowników. Przykładowo, przeszklony łącznik Wydziału Biologii pełni funkcję „małej palmiarni”, gdzie można podziwiać roślinność egzotyczną, a wśród niej bananowca, zaś przy budynku wydziału utworzono w 2009 r. zakątek bioróżnorodności. W 2012 r. na liście gatunków roślin kwiatowych tego terenu znalazło się 50 pozycji, uzupełnionych przez mchy i porosty, z czego 70\% stanowiły rośliny rodzime. Na patio Wydziału Nauk Geograficznych i Geologicznych zrealizowano projekt „kamiennej rzeki”, przy wykorzystaniu głazów narzutowych. Natomiast atrakcją przy Instytucie Geologii jest lapidarium petrograficzne, w którym znajduje się między innymi 20-tonowy głaz polodowcowy. Eksponaty zebrane w lapidarium zostały wykonane m.in.: z łupków, gnejsów skandynawskich, piaskowców czy granitu (Górska-Zabielska 2010). Obszar ten został podzielony na cztery działy: kamień w architekturze i rzeźbie, kamień w budownictwie drogowym, kamień w przyrodzie oraz kamień użytkowy (Lapidarium, Wikipedia; fot. 1 ).

Analizy przedstawione w pracy K. Jawgiela i D. Zajączkowskiego (2016) wykazały istnienie możliwości pokrycia zielenią fragmentów dachów poszczególnych wydziałów na Kampusie Morasko, który mimo że położony w otoczeniu zieleni, prawie w 30\% pokryty jest terenami antropogenicznymi, dlatego budowa zielonych dachów na tym obszarze jest uzasadniona. Aktualnie zastosowanie zielonego dachu ma miejsce na części dachu budynku Wydziału Geograficznego, natomiast na budynkach Archiwum UAM, Wydziału Fizyki oraz Wydziału Biologii rozwinęły się inne formy zielonej infrastruktury w postaci „zielonych ścian”. Wprowadzenie dodatkowej zieleni poprzez zakładanie zielonych dachów pomoże wzmocnić funkcje estetyczno-rekreacyjne oraz poprawić izolację termiczną budynków. 

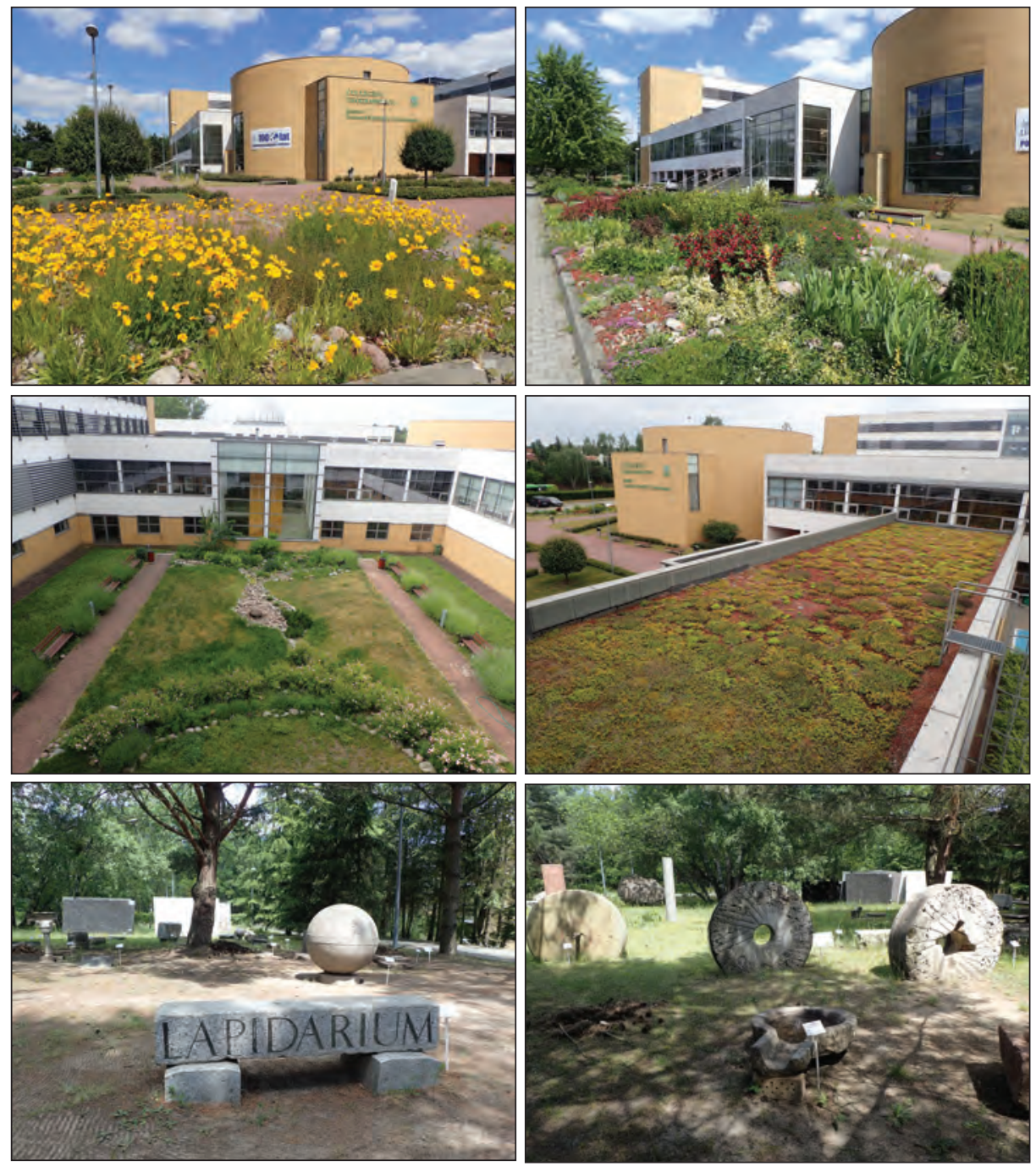

Fot. 1. Elementy zagospodarowania przyrodniczego Wydziału Nauk Geograficznych i Geologicznych (fot. B. Konecka-Szydłowska)

Photo 1. Elements of the natural development of the Faculty of Geographical and Geological Sciences (photo by B. Konecka-Szydłowska) 


\section{Zakończenie}

Przeprowadzone badania pozwalają stwierdzić, że w badanych latach przestrzeń publiczna Kampusu Morasko w Poznaniu jest coraz lepiej postrzegana przez studentów, o czym świadczy wzrost ocen we wszystkich badanych kategoriach. Można sądzić, że ma to związek z poprawą jakości i powiększeniem poszczególnych jej elementów, np. budowa nowych wydziałów czy poprawa ładu funkcjonalnego i zagospodarowania przyrodniczego. Zdecydowanie lepiej oceniają przestrzeń Kampusu studenci wydziałów zlokalizowanych w jego zachodniej części. Mniej pozytywny obraz Kampusu, który w ostatnich latach nie ulega zmianie, mają studenci Wydziału Nauk Geograficznych i Geologicznych. Jest to jedyny wydział zlokalizowany we wschodniej części Kampusu, który cechuje gorsza dostępność komunikacyjna i peryferyjność położenia względem pozostałych wydziałów. Taka lokalizacja powoduje, że studenci tego wydziału w mniejszym stopniu utożsamiają się z tym miejscem (przestrzenią), co wpływa również na gorszą percepcję pozostałych własności przestrzeni publicznej Kampusu. W takiej sytuacji rodzi się pytanie: czy słuszna była podjęta w latach 90. decyzja o przeniesieniu z centrum miasta do tej części Kampusu Instytutu Geologii, będącego częścią Wydziału Nauk Geograficznych i Geologicznych? Wybór takiej lokalizacji przyczynił się w późniejszym okresie (lata 2002-2006) do wybudowania w jego sąsiedztwie nowego gmachu tego wydziału, w którym siedzibę mają dziś pozostałe instytuty.

Zdecydowanie korzystnie należy ocenić walory przyrodnicze i zagospodarowanie rekreacyjne tej części miasta, która służy nie tylko studentom, ale też wszystkim mieszkańcom Poznania. W badanym okresie obserwuje się pozytywne zmiany związane ze stopniowym uzupełnianiem elementów infrastruktury społecznej i poprawą dostępności komunikacyjnej zachodniej części Kampusu. Z kolei na początku 2020 r. oddano do użytkowania nowe obiekty sportowe zlokalizowane w części wschodniej Kampusu, w których skład wchodzą m.in.: stadion lekkoatletyczny, boisko do piłki nożnej z nawierzchnią ze sztucznej trawy, tor dla rolkarzy, otwarty kort tenisowy i siłownia zewnętrzna. W planach na 2020 r. jest również rozpoczęcie budowy w części zachodniej Kampusu pierwszego nowoczesnego domu akademickiego dla 400 studentów wraz z przedszkolem, stołówką, minimarketem i klubem studenckim.

Zdaniem prof. Bogumiły Kaniewskiej, pełniącej od 1 września 2020 r. funkcję rektora UAM: „Morasko jest pięknym terenem, który ma ogromny potencjał. Naprawdę warto podejmować inicjatywy w tym miejscu. Warto działać, wykorzystywać te obiekty sportowe, rekreacyjne, które już mamy. Ale żeby tak się stało, powinny być spełnione pewne warunki. I o nich chcemy ze studentami rozmawiać" (Przysztość Kampusu Morasko 2018). Okazją do tego była pierwsza konferencja Przysztość Moraska, zorganizowana przez Radę Samorządu Studentów Wydziału Nauk Politycznych 
i Dziennikarstwa w maju 2018 r. Podczas konferencji studenci oraz przedstawiciele władz uniwersyteckich, miasta Poznania i Zarządu Transportu Miejskiego prowadzili dyskusje na temat zagospodarowania wspólnej przestrzeni Kampusu oraz kwestii komunikacyjnych, logistycznych i finansowych.

\section{Literatura}

Adamek P., 2017, Kampus Uniwersytecki Morasko w Poznaniu. Geneza powstania, rozwój, funkcjonowanie, praca licencjacka napisana pod kierunkiem dr B. Koneckiej-Szydłowskiej, Instytut Geografii Społeczno-Ekonomicznej i Gospodarki Przestrzennej UAM w Poznaniu.

Babbie E., 2005, Badania spoteczne w praktyce, Warszawa, PWN.

Bartoszek A., Gruszczyński L.A., Szczepański M.S., 1997, Miasto i mieszkanie w spotecznej swiadomości: Katowiczanie o Katowicach, Katowice, Śląsk.

Beim M., Modrzewski B., 2008, Dostępność transportowa i uktad przestrzenno-funkcjonalny kampusu uniwersyteckiego Morasko w Poznaniu, [w:] T. Markowski, D. Drzazga (red.), Rola wy:szych uczelni w rozwoju spoteczno-gospodarczym i przestrzennym miast, Studia KPZK PAN, 121, 297-310.

Bierwiaczonek K., Nawrocki T., 2012, Teoretyczne spojrzenie na przestræeń publicznq, [w:] K. Bierwiaczonek, B. Lewicka, T. Nawrocki (red.), Rynki, malle i cmentarze. Przestrzen publiczna miast ślaskich w ujęciu socjologicznym, Kraków, NOMOS.

Burgess, J., 1978, Image and identity: A study of urban and regional perception with particular reference to Kingston upon Hull, Kingston, University of Hull.

Cegłowska A., Matykowski R., 2010, Præestrzenie publiczne i ich znaczenie w du:ym mieście:przypadek Poznania, Studia Miejskie, 2, Wydawnictwo Uniwersytetu Opolskiego, Opole, 243-256.

Dębińska D., Kołsut B., 2011, Obsæary præestræeni publicznej w studium uwarunkowań i kierunków zagospodarowania præestræennego wybranych miast powiatowych wojewódætwa wielkopolskiego, [w:] P. Churski (red.), Praktyczne aspekty badań regionalnych - varia IV, Biuletyn Instytutu Geografii Społeczno-Ekonomicznej i Gospodarki Przestrzennej UAM, Seria Rozwój Regionalny i Polityka Regionalna, 16, Poznań, 99-106.

Górska-Zabielska M., 2010, Gtazy narzutowe w Wielkopolsce, Prace i Studia z Geografii i Geologii 18, 1-69.

Hładkiewicz W., 2006, Koncepcja prsestræeni publicsnej w teorii Jurgena Habermasa, [w:] P. Hudzik, W. Woźniak (red.), Sfera publiczna. Kondycja-przejawy-przemiany, Lublin, Wydawnictwo UMCS.

Jawgiel K., Zajączkowski D., 2016, Potencjat Kampusu UAM Morasko w aspekcie «agospodarowania dachow zielonq infrastrukturq, Acta Scientiarum. Polonorum Formatio Circumiectus 15 (4), 181-192.

Konecka-Szydłowska B., Dolata M., 2006, Kampus Morasko - nowa przestrzeń wstrefie peryferyjnej Posnania, [w:] I. Jażdżewska (red.), Nowe præestræenie w miastach, ich organiæacja i funkcje, Wydawnictwo Uniwersytetu Łódzkiego, Łódź, 117-129. 
Konecka-Szydłowska B., Kulczyńska K., 2012, Różnorodnośćw jedności. Przykład miast powiatu czarnkowesko-trzcianeckiego, Studia Miejskie, Opole, 5, 129-143.

Konecka-Szydłowska B., 2016, Ocena przestrzeni publicznej matych miast aglomeracji poznańskiej, Problemy Rozwoju Miast. Kwartalnik Naukowy Instytutu Rozwoju Miast, Kraków, XIII, 3, 5-12.

Kotus J., 1999, Zastosowanie skali dyferencjatu semantycznego do badań obrazu miasta w świadomości mieszkańców, [w:] Zróżnicowanie præestrzenne struktur spotecznych w dużych miastach, XI Konwersatorium Wiedzy o Mieście, Wydawnictwo Uniwersytetu Łódzkiego, Łódź, 91-95.

Kowalczyk J., 2009, Paradygmaty zmian w præestrzeni publicznej kobiet, Teka Komisji Politologii i Stosunków Międzynarodowych, OL PAN, Warszawa, 4, 18-28.

Kulczyńska K., Borowicz N., Piwnicka-Wdowikowska K., 2020, Kampus Uniwersytecki Morasko w Poznaniu - geneza, struktura przestrzenno-funkcjonalna, obstuga transportowa, Prace Geograficzne, 163, 7-32.

Lapidarium UAM w Poznaniu, https://pl.wikipedia.org/wiki/Lapidarium_UAM_w_Poznaniu (dostęp: 4.04.20)

Libura H., 1988, Badania wyobrażeń geograficznych na przykładzie mieszkańców Sanoka. Dokumentacja Geograficzna IGiPZ PAN, 1, 90.

Liszewski S., 2001, Præestræeń miasta postsocjalistycænego. Program badań, [w:] B. Korus (red.), C¿łowiek i præestrzeń, Kraków, Instytut Geografii i Gospodarki Przestrzennej Uniwersytetu Jagiellońskiego, 113-120.

Lorens P., 2007, Tematyzacja przestrzeni publicænej jako wyraz dywersyfikacji struktury urbanistycznej miasta doby globalizacji, [w:] M. Madurowicz (red.), Percepcja respótczesnej przestrzeni miejskiej, Uniwersytet Warszawski, Wydział Geografii i Studiów Regionalnych, 83-92.

Łukasiewicz A., 2005, Park na Morasku, Życie Uniwersyteckie UAM Poznań, 6 (146), 22.

Łukasiewicz S., 1998, Tworzenie naturalistycznego parku na terenie Uniwersytetu im. A. Mickiewicza w Morasku koto Poznania, [w:] Badania fiæjograficzne nad Polskq Zachodniq, Seria B - Botanika, PTPN Poznań, t. 47, 227-243.

Madurowicz M.,(red.), 2007, Percepcja wespótczesnej præestræeni miejskiej, Uniwersytet Warszawski, Wydział Geografii i Studiów Regionalnych, Warszawa.

Markowski T., 2007, Præestræeń publicæna wobec procesu metropolizacji, Urbanista, 7 (51), 10-15.

Mayntz R., Holm K., Hubner P., 1985, Wprowadzenie do metod socjologii empirycznej, PWN, Warszawa.

Mierzejewska L., 2011, Præestræeń publicæna sfery podmiejskiej (na przyktadzie Poznania, [w:] M. Wdowicka, L. Mierzejewska (red.), Problemy rozwoju lokalnego i regionalnego na poczqtku XXI wieku, Biuletyn Instytutu Geografii Społeczno-Ekonomicznej i Gospodarki Przestrzennej UAM, Seria Rozwój Regionalny i Polityka Regionalna, 15, Poznań, 86-97.

Osgood C.E., Succi G.J., Tannenbaum P.H., 1957, The Measurement of Meaning, University of Illinois Press, Urbana.

Pilch R., 2017, Wspótczesne tendencje w lokalizacji kampusów akademickich w matych i średnich miastach, rozprawa doktorska napisana pod kierunkiem prof. dr. hab. inż. arch. W. Bonenberga, Politechnika Poznańska, Wydział Architektury, Poznań. 
Przysztośc Kampusu Morasko, 2018, https://www.poznan.pl/mim/info/news/przyszlosc-kampusu-morasko,118396.html (dostęp: 15.06.20)

Słodczyk J., 2003, Præestræeń miasta i jej præeobrażenia, Studia i Monografie, 298, Uniwersytet Opolski.

Wódz K., 1991, Præestrzeń wielkiego miasta w perspektywie badań nad planowaniem i ṡywiołowościq, Uniwersytet Śląski, Katowice.

Barbara Konecka-Szydtowska (ORCID 0000-0003-2309-5690)

Uniwersytet im. Adama Mickiewicะa w Poznaniu

Wydziat Geografii Spoteczno-Ekonomicznej i Gospodarki Przestrzennej

Zaktad Studiów Regionalnych i Lokalnych

ul. B. Krygoweskiego 10, 61-680 Poznań

bako@amu.edu.pl 